\title{
多機能化を目指した折れ曲がり変形型内視鏡の開発
}

\section{Development of Bending Transformative Multifunctional Endoscope}

\author{
須田信一郎 (学生会員) ${ }^{\mathrm{a} *}$, 松永忠雄 ${ }^{\mathrm{b}}$, 芳賀洋一 ${ }^{\mathrm{a}, \mathrm{c}}$ \\ a 東北大学 大学院工学研究科 \\ $\mathrm{b}$ 東北大学マイクロシステム融合研究開発センター \\ $\mathrm{c}$ 東北大学 大学院医工学研究科
}

\author{
Shinichirou Suda ${ }^{\text {a* }}$, Tadao Matsunaga ${ }^{b}$, Yoichi Haga ${ }^{\text {a,c }}$ \\ ${ }^{a}$ Graduate School of Engineering, Tohoku University \\ ${ }^{b}$ Micro System Integration Center, Tohoku University \\ ${ }^{\mathrm{c}}$ Graduate School of Biomedical Engineering, Tohoku University
}

\begin{abstract}
The outer diameter of a rigid and flexible endoscope is limited because of the small incision for insertion of the endoscope, and thus it is difficult to incorporate several functions. In this research, a multifunctional bending transformative endoscope with a small diameter for insertion was developed. The tip of the endoscope is divided into three sections, and it can be transformed by manipulating wires from outside the body. Models of this bending type endoscope, which has two CCD cameras for $3 \mathrm{D}$ vision and rear view, were fabricated. Insertion of a forceps through its working channel was also demonstrated.
\end{abstract}

Key words

Electric endoscope, Bending transformative mechanism, Optical imager, Photofabrication.

\section{1.はじめに}

腹腔鏡下手術などの内視鏡下手術では，体表に小切 開を加え，そこに細径の硬性内視鏡や鉗子，切開ツー ルなどを挿入し，従来の開腹手術に匹敵する効果を挙 げることができる。内視鏡下手術は従来の開腹手術に 比べて切開部が比較的小さくできるため，患者にかか る負担が少ない。しかし挿入するツールの外径サイズ は限られているため, 1 本のツールに多数の機能を搭 載することは難しい。近年，内視鏡下手術の発展に伴 い, 内視鏡とそのツールには様々な高機能化・多機能

* 東北大学大学院工学研究科 芳賀研究室

干 980-8579 宮城県仙台市青葉区荒巻字青葉 6-6-12

E-mail : shinichirou-suda@m.tains.tohoku.ac.jp

受付 2012 年 1 月 27 日; 採択 2012 年 7 月 5 日
化が求められている 1)2). 一方で内視鏡ツールを体内 で組み立て，組織縫合を容易にする試みもなされてい る ${ }^{3)}$ 。また, Endo SAMURAI など複数のアームを実 装する内視鏡も開発されている ${ }^{4)}$. 多数の機能を搭載 することにより精度の高い手術が可能となる反面, 内 視鏡外径は太くなるため, より内視鏡の細径化が求め られる.今回は体内で内視鏡先端を 1 力所以上折り曲 げ変形させることにより,多機能化を実現しながらも， 体内挿入時は直線形状で径が小さく出し入れが容易な 内視鏡を開発した。

本研究では， 2 種類の変形型内視鏡モデルの試作を 行なっている。まず一つ目として三次元画像の取得を 可能とした内視鏡モデルを提案する．視覚情報として 従来の単眼の内視鏡で映し出された映像のみで手術を 


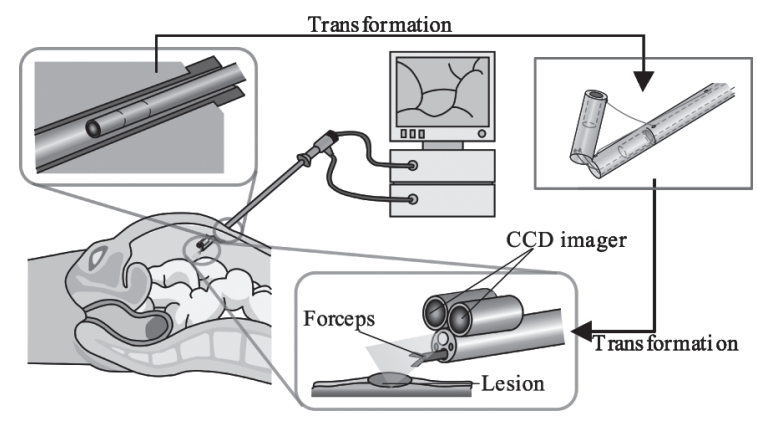

Fig.1 Conception picture of the bending transformative endoscope. (O.D. around $10 \mathrm{~mm}$ )

行なう際は，視野の確保・奥行きの情報が不足する

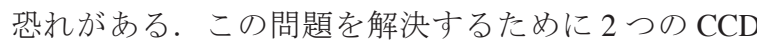
（電荷結合素子）カメラを用いて三次元（3D）の画像 を撮影する内視鏡も市販されている ${ }^{5)}$. 通常の立体内 視鏡では 2 つの $\mathrm{CCD}$ 素子を内視鏡の短軸方向に並心゙ て実装するため, 内視鏡サイズか観察の性能を犠牲に する必要があった．今回試作の内視鏡のコンセプトを

Fig. 1 に示寸．この内視鏡の用途の一つとして腹腔鏡 手術がある，微小な孔を通して一本の管として内視鏡 が通過した後，体内では内視鏡の先端部が折れ曲がり 変形することにより 2 つの CCD カメラを用いること が可能となる．内視鏡の先端は複数のリンク部と屈曲 部により構成されている。リンク部には，CCD 素子 等の機能の搭載が可能であり，それぞれに取り付けら れたワイヤを率引することにより屈曲部が折れ曲がり 変形が可能になる。変形後はリンクごとに搭載された 機能が治療部位方向に向き，リンク部に搭載された多 数の機能を使用することが可能になる．本研究では, 挿入時などは通常の二次元（2D）の視覚情報を用い, 治療部位など䋊細な操作が要求される個所においては 3D の視覚情報を用いることが可能になる。前述の内 視鏡変形機構を用い，多機能化を目的とした外径 10 $\mathrm{mm}$ の大径の腹腔用内視鏡の試作を行なった.

また試作の 2 つ目として更なる細径化・高機能化の ため，設計試作を行なった。細径化を実現することに より腹腔以外の部位にも変形型内視鏡を使用すること が可能になる。一例として，大腸などの下部消化管用 内視鏡ツールを試作した。大腸内視鏡検査は肛門から 内視鏡を挿入し，直腸や結腸に発生したポリープやが んを探し, 必要に応じ生検・切除が可能である。しか し，従来の大腸内視鏡は前方視であり，屈曲可能では あるが，曲率半径が大腸内腔に対し充分に小さくない ため，ヒダ裏に隠れたがんやポリープを見逃す恐れが

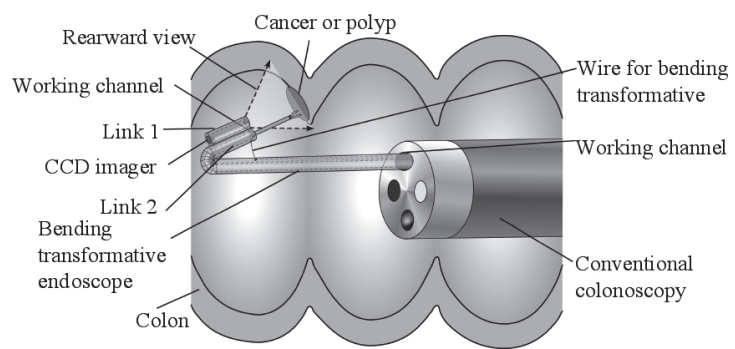

Fig.2 Conception picture of transformative endoscopic tool. (O.D. around $4 \mathrm{~mm}$ )

ある ${ }^{6)}$. 本研究では独自に開発した非平面微細加工技 術を用い，内視鏡の鉗子口を通して挿入するツールの 先端を折り曲げ変形させることにより多機能でかつ後 方視野を確保する細径変形型内視鏡を作製した（Fig. 2)。従来の大腸内視鏡の鉗子口から挿入し，変形後は CCD イメージャ，白色 LED（発光ダイオード），鉗子 を用いて後方の観察・治療を可能にする，本研究では， 前述の内視鏡变形機構を用い，細径化を目的とした外 径 $4 \mathrm{~mm}$ の細径の下部消化管用内視鏡を試作し観察と 屈曲動作をそれぞれ確認した。

\section{2. 腹腔鏡手術に用いる変形型内視鏡 \\ 2.1 変形型内視鏡の構成・作製}

今回作製する変形型内視鏡の先端は 3 区間に分けら れており，先端から 1 つ目の区間（Link 1）と2つ目 の区間（Link 2) にはそれぞれ光学イメージャ等の機 能を実装することが可能である。本研究では，Link 1 と Link 2 それぞれに LED 照明とレンズを備えた CCD カメラ（株アールエフ,多目的カメラ $\phi 5.5 \mathrm{~mm}$ )を搭 載し，内視鏡の変形後に 2 つの CCD カメラが治療部 位を向き $3 \mathrm{D}$ の視覚情報を得て治療が可能な変形型内 視鏡を作製した．チューブ内腔には CCD カメラの他， カメラの配線，超弾性合金ワイヤ，ワイヤを内部に通 寸薄肉ポリイミドチューブおよび鉗子口を確保するシ リコーンチューブが構成されている．Fig. 3(a) に内視 鏡の作製プロセスを，試作したデバイスの写真を Fig. 3(b) に示寸. 今回, 外壁は加工のしやすさからシリコー ンゴムチューブを用いており，壁の一部が折れ曲がり 部の関節を兼ねている。シリコーンゴムは軟性である ため，接触しても体内組織に損傷を与えにくい，壁面 の一部を屈曲部（長さ: $2 \mathrm{~mm}$ ）とするため，アウター チューブをカットし, カット後, Link 1 と Link 2 そ れぞれに光学イメージャ, 内視鏡根元部には処置具を 
(a)

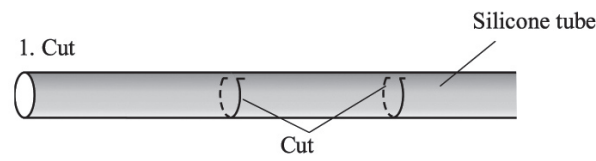

2. Mounting of CCD imager and inner tube (1) $i)$ CCD imager

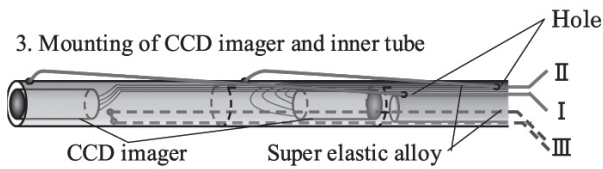

CCD imager

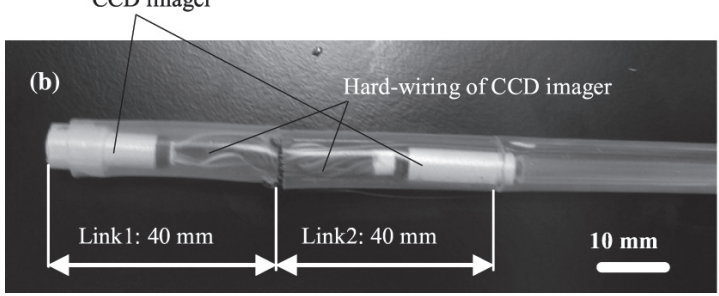

Fig.3 Bending transformative endoscope for laparoscopic application ; (a) Fabrication process, (b) Photo of endoscope.

挿入するワーキングチャネルを設置するためシリコー ンチューブ（外径 : $6 \mathrm{~mm}$, 内径 : $4 \mathrm{~mm}$ ）を実装する. 最後に牽引することで内視鏡を変形させるための超弾 性合金ワイヤ（径：0.3 mm）をLink 1 と Link 2 にそ れぞれ実装し，ワイヤの固定にはエポキシ樹脂接着剤 を用いた. リンク部に固定されたワイヤを手元に牽引 することにより，直線形状の内視鏡から，Fig. 1 右下 に示すように変形し，超弾性合金ワイヤ I ・ II を引い た分だけ押し込み，その後点線で示す超弾性合金ワイ ヤIIIを手元に引くことで直線形状への再変形を可能に している。体内の挿入時にはシャフトが折れ曲がらな いようにスタイレットを内腔に挿入するか, または薄 肉の硬性チューブを外側に覆せる予定である.

直線形状での外径は約 $10 \mathrm{~mm}$, 長さは $130 \mathrm{~mm}$, Link 1 および 2 の長さはそれぞれ $40 \mathrm{~mm}$ であり, CCD 部の直径は $5.5 \mathrm{~mm}$, 長さは $20 \mathrm{~mm}$ と設定した.

\section{2 折れ曲がり変形型内視鏡の動作確認}

Fig. 4(i) から (v) に折れ曲がり変形の様子を示す. Fig. 4(i) から (iii) までは超弾性合金 I を引いたとき, Fig. 4(iii) から (v) までは超弾性合金 II を引いたときを それぞれ表わしている. 変形後には Fig. 4(vi)のよう に鉗子を挿入できるほか，Fig. 5 のように 2 つの CCD それぞれからの像を得ることができ立体視の基礎的な 確認ができた．2つの CCD の距離を広くすることが でき，輻輳角が大きくなることから，立体視における
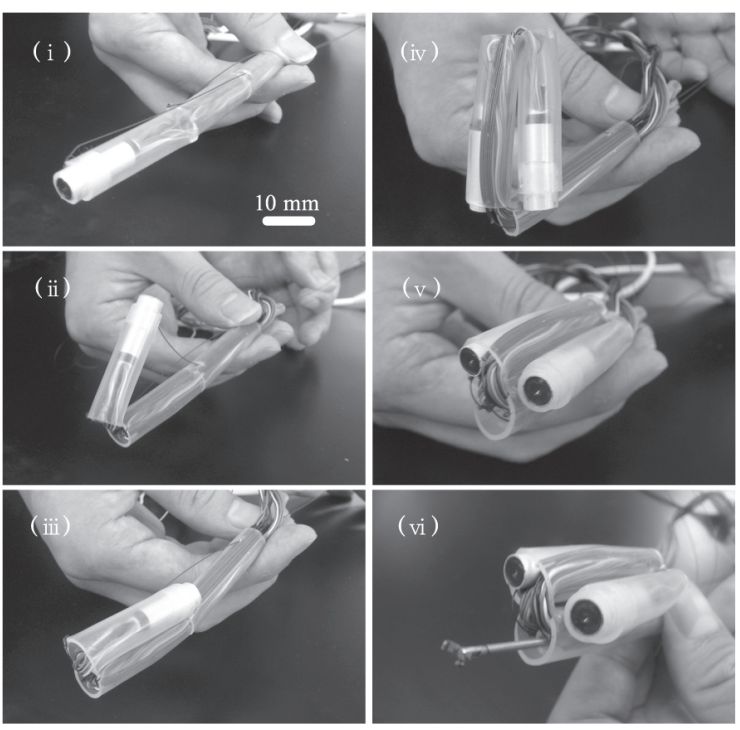

Fig.4 Transformation of the 3D endoscope.
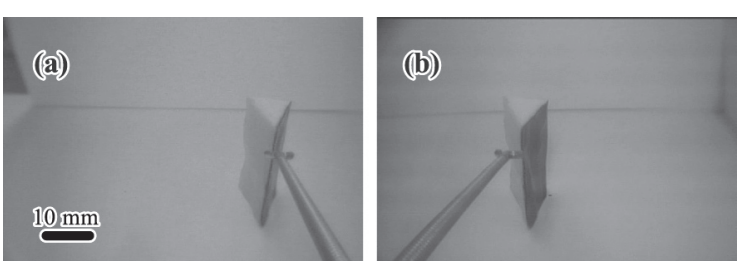

Fig.5 Images of two CCD cameras (a) Image of CCD camera of Link1 (b) Image of CCD camera of Link2.

深さ分解能を向上できる.さらに Fig. 3(a)のワイヤ I・ II を押し込み，IIIを引いて直線の一本管形状に戻すこ とが可能であった。

\section{3. 大腸ひだ裏観察治療に用いる変形型内視鏡 \\ 3.1 構成}

前述の腹腔鏡における変形型内視鏡の試作では, CCD イメージャの配線が大径であるため, 内視鏡の 細径化が困難であった．内視鏡が大径であるほど，挿 入する際患者への負担は大きくなる．鉗子口となる チューブ外側に，微細な銅配線を形成することにより 内視鏡細径化の実現を試みた。内視鏡の細径化を実現 することで従来の内視鏡鉗子口に，試作した変形型内 視鏡を挿入することも可能となる. 大腸ひだ裏観察・ 治療には, 従来の大腸内視鏡（外径約 $13 \mathrm{~mm}$ ) のワー キングチャネル（内径 $4.2 \mathrm{~mm}$ ) へ作製する変形型内 視鏡を挿入し, 変形させ後方視野を得て治療を可能に することを目的とする (Fig. 2).

内視鏡の先端は, Link 1 と Link 2 の 2 力所で分け られており, Link 1 には光学イメージャとイメージャ を駆動するための周辺回路が，Link 2 には高輝度白色 


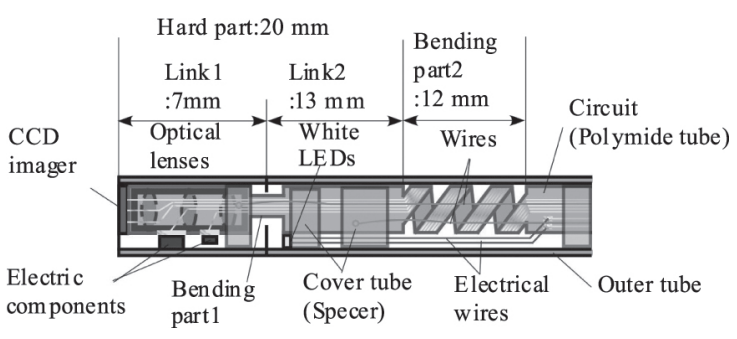

Fig.6 Structure of the bending transformative endoscope.

LED とワーキングチャネルが設置されている(Fig. 6). 光学イメージャ実装基板と, 屈曲機構配線部の一体化 を図ることにより内視鏡の細径化を実現している．以 上の円筒基板回路を作製し実装することで，外径 4.0 $\mathrm{mm}$ 以内，硬性部長さ $20 \mathrm{~mm}$ の細径内視鏡の実現を 目指す．内視鏡の変形には，上述と同様にワイヤによ る率引方法を用いており, 屈曲部 1 , 屈曲部 2 を折り 曲げ変形または屈曲させることにより，Link 1 で後方 視野の確保を行ないながら， Link 2 に設置されている ワーキングチャネルから処置具を挿入し治療を実施す ることが可能になる。

\section{2 撮像部の作製}

内視鏡は細径かつ先端の硬性部が短いほど挿入性に 優れ，患者への負担が軽減される。内視鏡は円筒形状 をしているため，平面形状の光学イメージャ用配線基 板では内視鏡の細径化を行なう際に実装が困難とな る。そこで本節では，新たに円筒形状の配線回路基板 を設計試作した. 硬性部を短くすることも可能になり， 細径な内視鏡を実現することができる。円筒基板には 外径 $1.92 \mathrm{~mm}$, 厚さ $0.06 \mathrm{~mm}$ のポリイミドチューブを 基板として用いる. フォトファブリケーション技術に より細径な配線回路を作製し，配線回路を形成後に レーザーアブレーションを施すことで屈曲部の加工を 行なった ${ }^{7) 8)}$. Fig. 7 に円筒基板の作製プロセスを示す.

\section{1) 銅シード層の作製}

後に行なら銅電解めつきのシード層となる銅を，ポ リイミドチューブ基板上にスパッタリングを行ない, 成膜した，円筒基板上へ均一に成膜するため，円筒基 板を一定速度にて回転させながら厚さ約 $200 \mathrm{~nm}$ の成 膜をする。

\section{2) フォトレジストの塗布}

基板上に均一な厚さのポジ型フォトレジストを塗布 するにあたり円筒基板を回転させながらフォトレジス トを霧化したスプレーコーティングを行なう。レジス

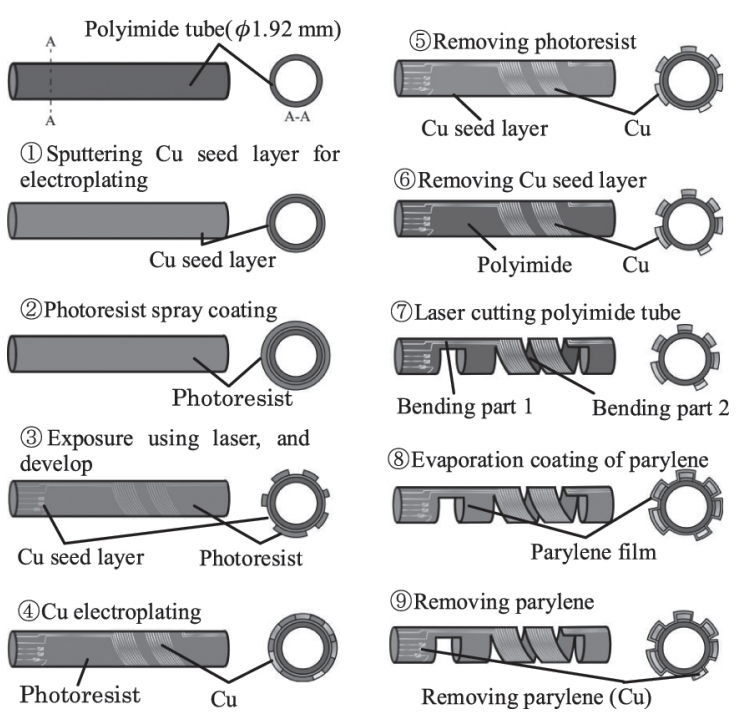

Fig.7 Fabrication process of cylindrical circuit board by rotational non-planar photofabrication process.

ト厚さを $40 \mu \mathrm{m}$ と設定した。

\section{3) 露光 · 現像}

円筒基板上に塗布されたフォトレジストを露光・現 像するため，バイオレッドレーザと多軸精密自動ス テージを組み合わせることにより点描画によるマスク レス露光を行なう．Fig. 8 に装置概要図を示す．光源 には $405 \mathrm{~nm}$ 波長のレーザを用いており，レーザ径の 調節も可能である。配線幅を $100 \mu \mathrm{m}$ と設定し露光を 行なう。

\section{4) 銅電解めっき}

露光・現像により作製されたフォトレジストを型と して，厚さ $30 \mu \mathrm{m}$ 銅の電解めつきを実施する.

\section{5) フォトレジストの除去}

銅電解めっきの型として用いたフォトレジストをア セトンにより除去する.

\section{6) 銅シード層の除去}

電解めつきに用いた銅シード層を塩化第二鉄溶液に 浸しエッチングをすることにより目的の配線パターン を得る。作製した銅配線を Fig.9 に示す.

\section{7) レーザ加エによる屈曲部の作製}

屈曲部を作製するため，Nd-YAG レーザ装置と精密 自動ステージを組み合わせたレーザアブレーション加 工装置を用いる。屈曲部 1 では折れ曲がった後に鉗子 口が確保できるように横一列に並んだ直線形状にレー ザ加工を施し，また屈曲部 2 では円筒基板の内腔を通 る鉗子を折れ曲がり時に保持させるため螺旋状に加工 を行なっている。レーザの波長には, 第三高調波（355 


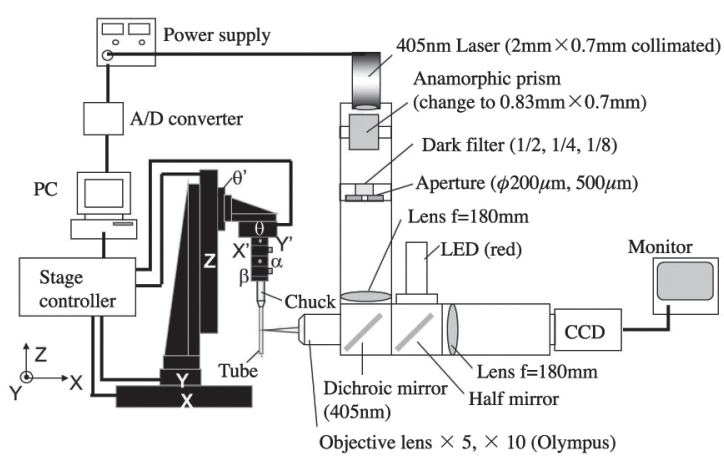

Fig.8 Laser exposure system.

nm）により，レーザアブレーションを実施した.

8) 絶縁層の成膜

屈曲機構部は配線がむき出しになっているため, 安 全面から絶縁をする必要がある。そこで円筒基板上の 配線に，薄膜のコーティングをする．コーティングと してパリレン（ポリパラキシレン）を用いた。パリレ ンは, 電気的絶縁の性質をもっているため, 絶縁層と して設けることが可能である。試料表面全域に均一な 成膜を行なっている.

\section{9) パッド部上の絶縁層除去}

CCD を駆動するための周辺回路を実装するため, 実装箇所となるパッド部上のパリレンの除去をした. 除去にはNd-YAG レーザ装置（第三高調波 $355 \mathrm{~nm}$ ) より, レーザアブレーションを行なった.

\section{0) 周辺回路の実装}

パリレンを除去したパッド上に周辺回路の実装を行 なった。

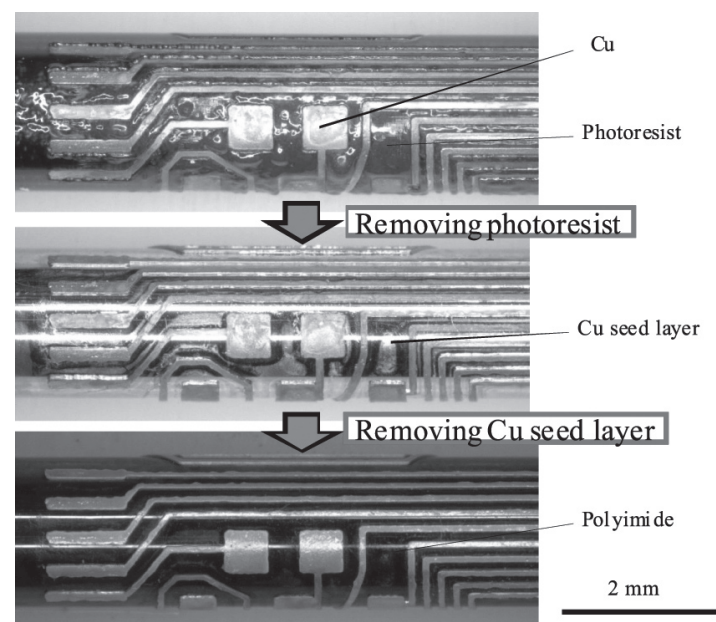

Fig.9 Fabrication process from $\mathrm{Cu}$ electroplating to removing $\mathrm{Cu}$ seed layer.

\section{3 動作確認}

作製した変形型内視鏡の屈曲パーツを Fig. 10 に示 す。また，Link 1 に実装したCCD イメージャと光学 レンズを Fig. 11 に，アウターチューブを実装した変 形内視鏡を Fig. 12 示す. 作製した内視鏡ツールは, 外径 $4.0 \mathrm{~mm}$, Link 1 が $7 \mathrm{~mm}$ [CCD イメージャとレン ズを含めると約 $9 \mathrm{~mm}$ ], Link 2 が $13 \mathrm{~mm}$ と細径かつ 硬性部を短くすることができた，今回は，長さ $40 \mathrm{~mm}$ の内視鏡変形部先端の作製を実施しており，今後，内 視鏡後方にはシリコーンチューブ等の軟性パーツを接 続する. CCD 駆動用の配線は，ボンディングパッド を介して配線となるワイヤを接続し，軟性パーツとな るチューブに通す。屈曲パーツの機械的特性を評価 するためCCD イメージャー・アウターチューブを実 装し評価を行なった。今回作製した内視鏡は Fig. 13,

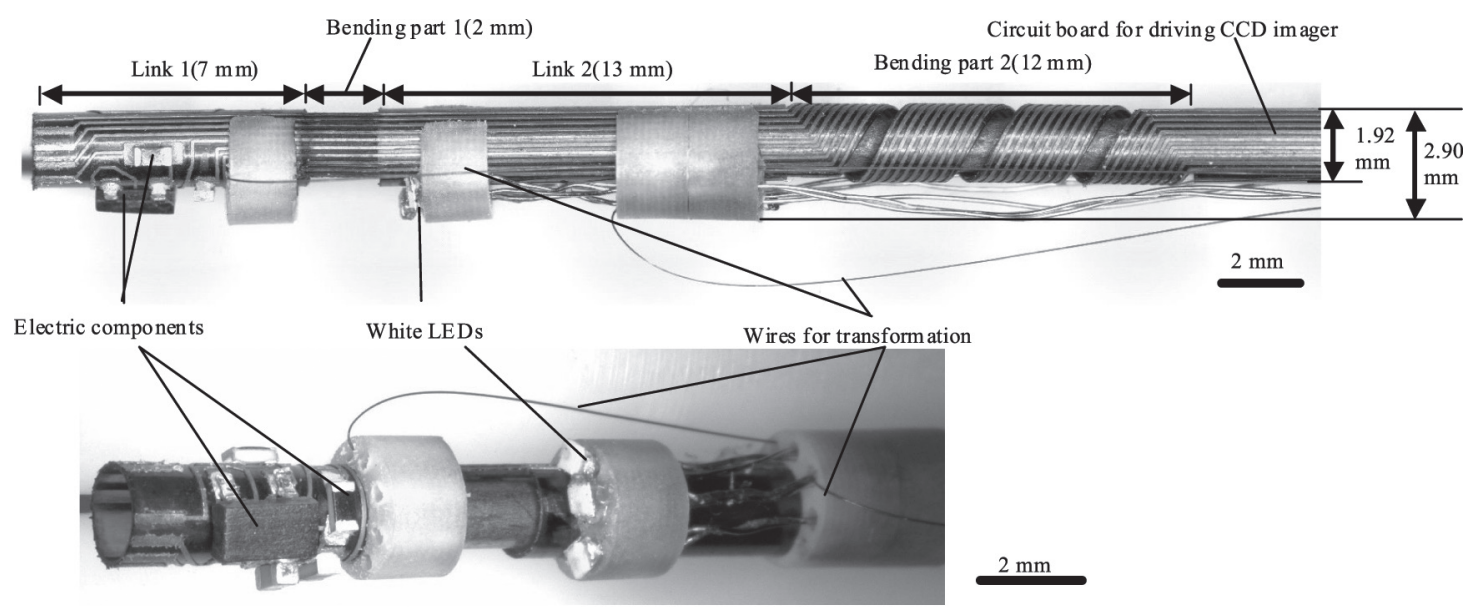

Fig.10 Overall view of fabricated endoscope. 


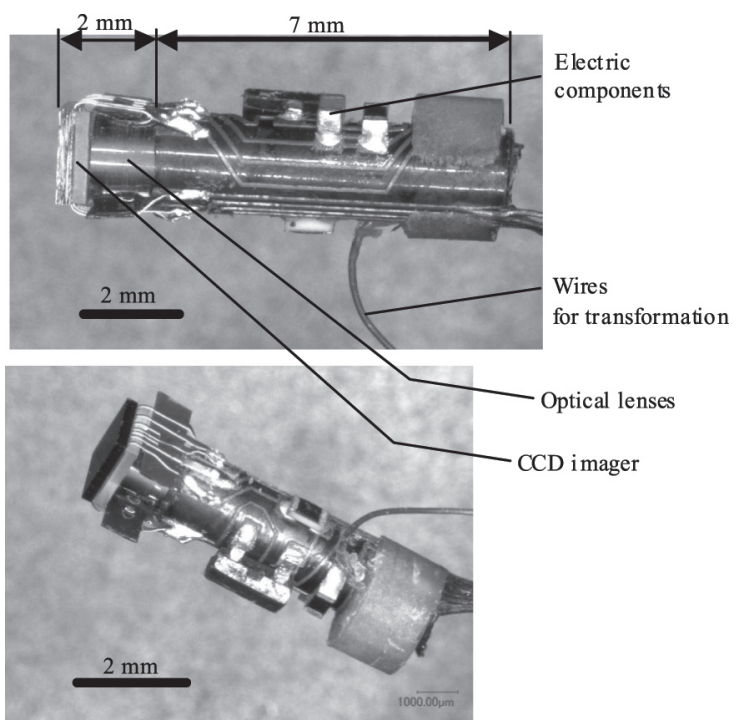

Fig.11 Mounting of CCD imager and optical lens.

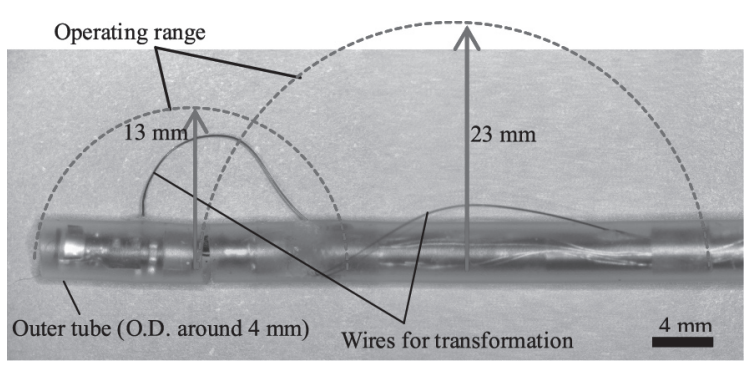

Fig.12 Mounting of outer tube.

Fig. 14 に示すように, 屈曲部 1, 屈曲部 2 ともほぼ 最大 $180^{\circ}$ まで屈曲させることが可能であった．また， 屈曲動作における銅配線の断線等は見られなかった。

\section{4. 考察}

今回，直線形状での外径が約 $10 \mathrm{~mm}$, 長さが 130 $\mathrm{mm}$, 内視鏡硬性部が $80 \mathrm{~mm}$ (Link 1 長さ: $40 \mathrm{~mm}$, Link 2 長さ:40 mm) の変形型内視鏡 (Fig. 3)を作製し, 内視鏡の変形後リンクごとに実装された機能を駆動さ せながらワーキングチャネルから処置具を挿入し鉗子 の操作が可能であることを確認できた. $47 \mathrm{~mm}$ 以内 の管内であるならば，いずれの屈曲部も $180^{\circ}$ 折り曲 げることが可能であり，内視鏡を自由に変形させるこ とが可能である．このことから，腹腔・胸腔等に使用 することができると考えられる。今回作製した変形型 内視鏡は，ワイヤ牽引で変形する点は従来の軟性内視 鏡と同じであるが，リンク接続部の折り返しによる変 形により多機能化をした点が新しい. 変形用のワイヤ の配置を工夫することで，ワイヤ牽引による再直線化 (a)
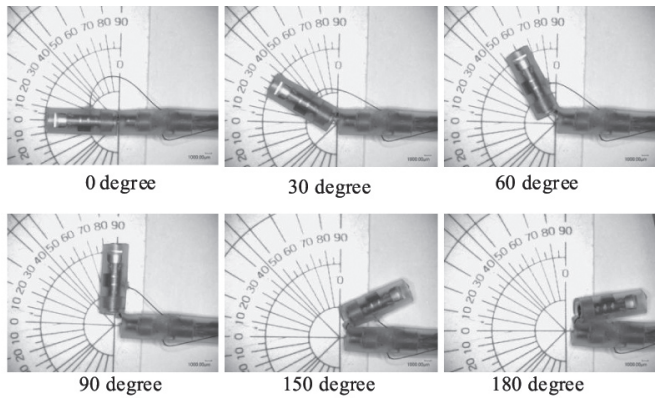

(b)

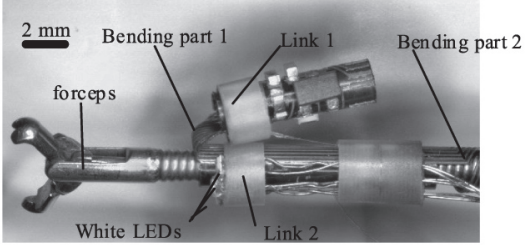

Fig.13 Transformation of fabricated endoscope; (a)Transformation of bending part 1, (b)Insertion of forceps after transformation.

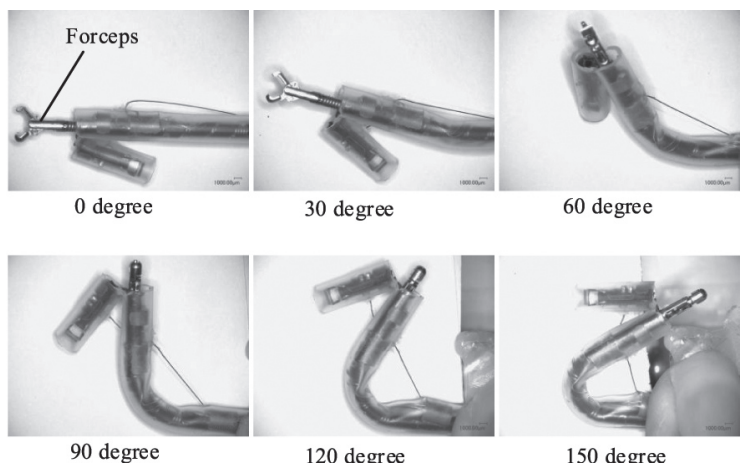

Fig.14 Transformation of bending part 2.

も可能にした．複数個のリンクを直列にすることで多 段の折り返しによる，さらなる多機能化ができる.

Fig. 5 に示したように，それぞれのリンクに実装さ れたイメージャから撮像した観察視点には角度差が生 じており, 立体視の基礎的な確認が行なえた。しかし， 今回の設計では，内視鏡のアウターチューブ壁面の一 部が関節部を兼ねているため，立体視を得る際，一定 に固定されるべき輻輳角が変形ごとに誤差が生じてし まい正確な立体視野を得られない。将来的には，屈曲 部を蝶番構造にするなどの改良が必要となる可能性が ある。また，現段階では屈曲の際，電気配線が剥き出 しとなっているため, 今後配線周囲にカバーを設ける 必要があると考えられる。

大腸などの下部消化管用細径内視鏡ツールの試作で は，実装する機能を変えさらなる細径化を行なった． 屈曲機構はプログラム位置制御によるレーザアブレー ションにより, 直線形状 (屈曲部 1) と螺旋形状 (屈曲 
部 2)の 2 種類の変形機構を作製している. 今回作製 した内視鏡は, 内径 $40 \mathrm{~mm}$ 程度の管では屈曲部 1 を $180^{\circ}$ 折り曲げ, 屈曲部 2 を最大 $180^{\circ}$ まで屈曲させる ことが可能であり, $23 \mathrm{~mm}$ 以内の管内であるならば, 内視鏡を変形させることが可能である (Fig.12).

本研究では, 外径約 $4 \mathrm{~mm}$ の変形型内視鏡を作製し ており，現段階では鉗子ロが $4.2 \mathrm{~mm}$ の大腸内視鏡へ 挿入することを考えている．この際，変形型内視鏡亡 鉗子口の隙間は最大 $0.2 \mathrm{~mm}$ であり, 従来の大腸内視 鏡が屈曲する際 Link 1,2 の硬性部が鉗子口内を通過で きなくなる恐れが生じる。今回作製したサイズについ ては，従来の大腸内視鏡の鉗子口内に，作製した変形 型内視鏡を予め挿入しておくことが必要であると考え られる．設置の際は従来の大腸内視鏡の硬性部に，変 形型内視鏡の硬性部 (Link 1,2) が位置する必要がある. また，体外から従来の大腸内視鏡鉗子口に挿入する際 は，現在の構成では特定の曲がる方向に対し, Link 1,2 を合わせたより長い硬性部として取り扱わなければな らないことから, 将来的にはLink 1,2 部の短縮化をす る必要性がある。今後, より細径なイメージャを用い ることにより，細径変形型内視鏡を作製し，鉗子ロ の挿入を可能にすることを考えている.

また，内視鏡を屈曲させる際，牽引するワイヤが内 視鏡外に露出しているが，生検鉗子において同様に屈 曲させる際，率引ワイヤを露出している鉗子も存在す $3^{9)}$. 今後, 変形型内視鏡の露出しているワイヤに関 して, 使用部位に応じて適切な対応をする予定である.

今回, 屈曲パーツの機械的特性を評価するため CCD イメージャおよびアウターチューブを実装し屈 曲評価を行なった (Fig. 14). 鉗子を挿入し内視鏡の先 端を 180 度屈曲させた状態で，鉗子の開閉を行なうこ とは可能であった。しかし，屈曲部 2 を曲げるとアウ ターチューブが潰れてしまい鉗子の挿入がし難くなる 問題点が挙げられる. 今後, 屈曲部 2 の鉗子口となる ポリイミドチューブとアウターチューブの間にステン レスばね等を設置し，アウターチューブの座屈により 鉗子口が押しつぶされない機構設ける必要があると考 えられる.今回作製した円筒基板の材質はポリイミド であり，その表面に銅配線を形成している。ポリイミ ドと銅配線の密着力は，電子部品を実装・使用する上 では充分であるが，再実装のために電子部品の取り外 しを行なう場合，配線部が剥がれてしまう恐れがあ る。そのため，電子部品を円筒基板上に正確に実装す る方法を検討する必要があると考えられる。 また, 作
製した配線はパリレンコーティングにより絶縁されて おり，配線周囲をパリレンが囲む構成になっているこ とから配線の断線等が生じにくい.さらに内視鏡操作 時における衝撃に対する安全策としては今後，エラス トマー等を電気配線周囲に塗布しカバーする，または 密バネ等を配線周辺に設置し外力から断線等を防ぐ手 段を講じる予定である.

本研究では細径化を実現するため, フォトファブリ ケーション技術を用いている。将来的にはさらなる細 径化を行なうことで変形型内視鏡は, 腹腔・大腸の他, 小腸・眼球・膀胱・心臓・胎览がいる子宮内・脳室 胸腔・鼻腔など様々な部位においても小さな切開で挿 入性を確保しながら自由度の高い様々な検査・治療を 提供できる手段になると期待される.

\section{5. 結言}

内視鏡の変形機構を備えた，対象部位の異なる腹腔 用硬性内視鏡亡大腸用細径内視鏡を作製した。これら の内視鏡は従来の内視鏡と異なり, 内視鏡の先端に複 数のリンクを設けており, リンクごとに設置されたワ イヤを牽引することにより変形を可能にしている．変 形後，実装されていたリンク内の機能を使用すること が原理的に可能である。作製した大腸用内視鏡は，屈 曲部 1 と屈曲部 2 の折り曲げ動作の確認が可能であり, 内視鏡の先端を多自由度で屈曲させられることが確認 できた．今回開発した折り曲げ変形型内視鏡の結果か ら，既存の内視鏡では到達が難しいとされていた内臓 の裏側への回り込みや大腸ひだ裏において観察・治療・ 診断が可能な内視鏡の実現の可能性を示した.

\section{*}

謝辞：本研究の一部は, 文部科学省 科学研究費補 助金 基盤研究 (B)「次世代型軟性内視鏡治療デバイス」 によるものである.

\section{文献}

1) Schurr MO, Schostek S, Ho C, Rieber F, Menciassi A. Microtechnologies in medicine: An overview. Minimally Invasive Therapy 2007; 16(2): 76-86.

2) 熊井浩一郎. 切開剥離特殊スコープ. 消化器内視鏡 $2005 ; 17(6) ; 875-878$.

3) 高山俊男, 小俣透, 田中直文, 小嶋一幸. 腹腔内組立式夕 バコ縫合器の開発. JJSCAS 2008: 10(2); 131-138.

4) Spaun GO, Zheng B, Swanström LL. A multitasking platform for natural orifice translumenal endoscopic surgery (NOTES): 
454 ～J JSCAS vol.14 no.4 2012

a benchtop comparison of a new device for flexible endoscopic surgery and a standard dual-channel endoscope. Surg Endosc 2009; 23: 2720-2727.

5) 神保昌夫, 佐藤一雅. 立体内視鏡装置. 特公 1995-20388.

6) Triadafilopoulos G, Li J. A pilot study to assess the safety and efficacy of the Third Eye retrograde auxiliary imaging system during colonoscopy. Endoscopy 2008; 40(6): 478-482.

7) Goto S, Matsunaga T, Totsu K, Makishi W, Esashi M, Haga Y. Micromachines and Applied Systems: Photolithography on Cylindrical Substrates for Realization of High-Functional Tube-Shaped Micro-Tools. Proceedings of the 22nd Sensor Symposium on Sensors, 2005: 112.

8) 牧志涉, 池田雅春, 江刺正喜, 松永忠雄, 芳賀洋一. 使い 捨て化と細径化を目指した形状記憶合金を用いた能動 屈曲電子内視鏡の開発. 電気学会論文誌 E 2011; 131(3): 102-110.

9) Ishii K, Itoi T, Sofuni A, Itokawa F, Tsuchiya T, Kurihara T, Tsuji S, Ikeuchi N, Umeda J, Moriyasu F. Novel Biopsy Forceps for Diagnosis of Biliary Tract Diseases during Endoscopic Retrograde Cholangiopancreatography:A Prospective Comparative Study with $90^{\circ}$ Adjustable and Conventional Biopsy Forceps. Hepatogastroenterology. 2012 Jul-Aug;59(117):1350-3 